\title{
Metaphor of Child Labor: Is it always negative? A Narrative Analysis
}

\author{
Nyuiemedi Agordzo Edoh-Torgah \\ University of Education, Winneba, Ghana \\ naagordzo@gmail.com
}

\begin{abstract}
This paper explored how children caught up in child labor understand their experiences and positive outcomes. The qualitative narrative analytic approach was used to gather data through interviews with six participants: four students from two public Junior High Schools and two mothers. The study found that some child laborers find positive personal meaning in their suffering which promoted freedom, responsibility and improved school enrolment and educational achievement. Issues such as financial literacy, self-support and economic independence were found to be positive outcomes of their experiences. We concluded that positive personal meanings motivated child laborers to improve on their here-and-now and have hope for the future. We called for community counseling for parents and children to manage their time and funds appropriately and profitably; to help child laborers to have deeper meaning of their conditions and to have positive feelings and outlook on life.
\end{abstract}

Keywords: child work, child labor, positivity, counseling, narrative analysis

Received I IJuly 2018/Accepted 29 November 2018 CJEHCP All rights reserved

\section{Introduction}

Children generally contribute to their household management through services such as running errands, washing, cooking, and caring for younger children. These contributions could sometimes be pushed further as moving away from child work to child labor. Child labor is a social problem globally. Child labor has been a way of life through most histories. The conventional perception is that child labor is bad: it is negative and offers nothing worthwhile (Basu \& Van, 1998). It is a common held assumption that child labor brings about negative feelings of shame, inferiority complex, anxiety (Al-Omoush, 2008; Grootaert \& Patrinos, 1999) and social isolation (Agordzo, 20II).

In Africa, the tragedy of child labor is huge and worrisome due to high poverty and poor schooling programmes (Wardlaw, You, Newby, Anthony, \& Chopra, 2013). The ILO in 1992 
conducted a research in Ghana and Senegal which revealed that Africa is one of the poorest continents in the world with ever increasing child labor figures. According to the Ghana Living Standards Survey (2008) report, there is high rate of non-school attendance coupled with wide gender disparities and entrenched cultural values regarding children's work (Agordzo, 20II).

\section{Conceptual and Theoretical Perspectives}

Studies revealed that the issue of child labor has some variations in definition (Donnellan, 2002). Child labor varies from person to person and across cultures (Epie, 2004). Since definitions are generalisations, the term "child labor" can then be defined culturally and in positive terms on the basis of a person's subjective experience. The concept of child labor is defined as work which does not take place under such relatively idyllic conditions. It is assumed to have a degree of economic compulsion associated with it and it involves a time and energy commitment which affects children's abilities to participate in leisure, play and educational activities, and that it impairs the health and development of children (Fyfe, 1989; Whittaker, 1989). These theorists argued that work cannot necessarily be termed child labor unless it detracts activities such as leisure, play and the education of the child. From the propositions of both Fyfe and Whittaker, child labor could be either good or bad depending on the social context in which the work takes place.

Child labor is perceived by many as only occurring in commercial areas and not within their households and in the supposed comfort and confines of parents and close relatives. It is imagined to be occurring in the mines, industries and on the streets. On the contrary, child labor takes place anywhere and in any form once the activity is hazardous and detrimental to the child's total development such as health, education and socialisation. Child labor is typically connected to exploitation and deprivation of the health, education and leisure of children and mostly seen as negatively impacting on the personal-social and vocational lives of its victims (Agordzo, 20l3).

The core issue of this paper is the positive personal meaning creation and value found in experiences of child labor by children who experienced it. This study explores the 
existential approach to counseling to understand the meaning that these individuals have of their traumatic experiences of child labor. Existentialism posits that suffering is an ineradicable aspect of life hinging on personal meaning drawn from suffering, meaning that could be "rationalization or justification of the unjustifiable" (Kottler \& Brown, 1996: p. 102). In as much as one is not advocating for child labor, it is pertinent for one to also understand that in the face of life's adversity that one has no control, it is better to make the best out of a bad situation. Individuals have choices: to break or be broken, to be free or imprisoned and, to create or be created. Individuals who transcend their difficult situations are those who possess the ability to choose freedom, creativity, and meaning in order to move into a more authentic existence (May, Angel, \& Ellenberger, 1958).

A large body of research has followed the seminal theoretical model of child labor by Basu and Van (1998) which posited that child labor is bad in household preferences by assuming a negative stigma of child labor in households, partly created by negative stigma of child labor in a community. A large part of empirical research of child labor has examined negative stigma cases (Arends-Kuenning \& Duryea, 2006; Emerson \& Souza, 2007; Patrinos \& Psacharopoulos, 1997). Of the existing research, only Lopez-Calva (2002) and Patrinos and Shafiq (2008) have modeled a positive stigma of child labor.

These models indicated that child labor is associated with positive stigma. Positive stigma of child labor is defined as approval of child labor in which households take pride in especially if the child combines his or her work with schooling (Lopez-Calva, 2002; Patrinos \& Shafiq, 2008; Admassie, 2003; Patrinos \& Psacharopoulos, 1997). Zierold, Garman, and Anderson (2004) were also of the view that child labor provides child laborers positive self-identity and self-reliance and autonomy over their pay or money. Patrinos and Psacharopoulos (1997: p. 398) in a study observed that Peruvian children combine employment with schooling to a large extent than children in other countries. They stated that "working actually makes it possible for the children to go to school." It is at the background of these that this current study interrogates the issue of whether there is any positivity in child labor in spite of its negative effects on individuals and communities. 


\section{Statement of the Problem}

Many international (ILO, IPEC, UNICEF) and national organisations (Ministry of Women and Children's Affairs and Social Protection, Ghana National Commission on Children, National Commission on Civic Education, Domestic Violence and Victims Support Unit, and Commission on Human Rights and Administrative Justice) have been tasked to eliminate child labor. The attempts by these and other organisations have been seen by all purpose and intent, as yielding not much dividend not only to the individual child laborer, but to his society and nation as well. The problem has received several condemnations that one wonders whether anything good can ever come out of child labor. Just as one is not denying the dangers involved in the practice, it is, however, prudent for researchers and advocates to take a second look at the call on the total elimination of child labor to managing it to the advantage of its victims.

\section{Purpose of the Study}

This study sought to explore plausible positive personal meaning and positive outcomes of child labor for the child and what counseling implications it has for future development. In this regard, this paper sought to answer the questions (I) How do children engage in child labor understand their conditions? (2)What are the positive outcomes of child labor for its victims?

\section{Significance of the Study}

This study aims at unearthing the positive personal meanings and effects of the phenomenon of child labor and to create awareness among counselors and NGOs/advocates on the maximization of these effects towards the reduction of the negative consequences of the phenomenon. 


\section{Method}

Qualitative method

This paper explored the positive personal meanings and outcomes of child labor. It is a part of a research project on socio-cultural context of child labor in fishing communities in the Cape Coast Metropolis of Ghana. This study employed the narrative analytic approach of the qualitative methodology (Miller, 1983; Mishler, 1986; Riessman, 2004) as a research design to gather data through narrative interviews. With the existential theory on how individuals make meaning out of their meaninglessness and have choice to be what they want to be, the philosophy of narrative analysis which shifts attention from "what actually happened", to how "people make sense of what happened" to them (Bryman, 2008: p. 556) becomes appropriate for this study. Narrative analysis is a kind of life history research that accounts for episodes and their interconnectedness. Through snowball sampling procedures, six research participants made up of four Junior High School students and two mothers were recruited into the study. The students comprised three boys and one girl who told their stories and outcomes of child labor. The core data analyses were based on the narratives of the student-participants who were the child laborers since they "are the primary sources of knowledge about their views and experiences" (Christensen \& Prout, 2002), 48I). The parents' narratives provided for triangulation.

\section{Data Collection Procedure}

Data were gathered through narrative individual interviews and focus group discussion. The narrative interviews sought to find out what personal positive meanings and effects school children involved in child labor have about their experiences. Interview with students lasted approximately 45 minutes and were conducted twice while the two parents were put together for a discussion that lasted for about an hour.

\section{Data Analysis}

In narrative analysis, the assumption is that researchers identify embedded meanings of the narratives of participants. To analyse data, the narrative interviews were read and re-read, 
coded and recoded with reflective notes written against them. Emergent themes were produced through the discovery of recurring phenomena noting the associations between and amongst them. These associations were based on the relatedness and contrast of themes that emerged all pulled into a family of themes. Acronyms and pseudonyms were used to code texts of participants for easy identification and anonymity.

\section{Establishing Trustworthiness of Data and Data Processes}

In a qualitative study, one attempts to establish trustworthiness and confirmability by employing several strategies that reduce researcher bias and establish verification (Padgett, 2004). Prolonged engagement, member checking, and triangulation were employed to collect data, and both in vivo and a priori themes were used to code and analyse data. Informed consents were duly sought. Pseudonyms were used for each interviewee to ensure confidentiality and enhance identification.

For the purposes of consistency (Creswell, 2003; Miles, Huberman, Huberman, \& Huberman, 1994) a senior lecturer also independently recoded the texts. The level of consistency received after the code-recode technique ranged between $80 \%$ and $92 \%$. To provide a sense of inter rater reliability to the study, an independent researcher was consulted to assess the work to find out whether or not the findings, interpretations and conclusions are supported by the data. This also provided a positive result of the findings and interpretations being data driven.

\section{Ethical Considerations}

This study considered the special needs of the population who were vulnerable victims of a social phenomenon (Creswell, 2003). The research established counseling ethics as its pillars before, during and after data collection. These included: acceptance, positive regard and the worth of the participants. I duly sought informed consent of the parents, teachers and participants through explanation of the rationale behind the study and the possibility for one to withdraw at any given time. Participants were assured of maximum confidentiality and anonymity. Bearing in mind the sensitivity of the topic and the vulnerability of the 
participants, an arrangement was made with a senior professional counselor to offer counseling services before, during and after the study should the need arise.

\section{Result}

The main findings are presented thematically in line with the research questions that guided the study. Research question I sought to explore child laborers' understanding of their child labor experiences. The research question 2 interrogated the positive outcomes embedded in the phenomenon. Two major themes with their subthemes emerged from the data: I) positive personal meaning of child labor, and 2) positive outcomes of child labor.

\section{Positive Personal Meaning}

Regarding participants understanding of child labor, the major theme emerged was positive personal meaning arising from child labor experiences. The following themes emerged here: freedom, responsibility, and educational attainment.

\section{a) Freedom}

To participants, work (during child labor) means freedom in several ways such as financial, physiological and moral. Participants were of the view that work provides them the opportunity to make money and to depend on themselves. Their understanding was that, though the conditions under which they worked were difficult, full of suffering, life is suffering and through suffering they have the choice to be free. The following excerpt reveals this:

Once I work for myself, take care of myself and family, I'm free.

I don't depend on anyone. (Koko)

However, Chris was of the view that, "our freedom does not mean that we don't respect our parents. We do. But just that we provide for ourselves and choose our friends". This freedom they have chosen to save their money and become financially independent of their parents and care givers. Not only are they free with the money they make, but also have the freedom to determine their friendships. 


\title{
b) Responsibility
}

Responsibility emerged as a crucial understanding of child labor to participants. They reported that working as a child means to be responsible: responsible for themselves and their family survival. Dan reported, I worked for my mother and siblings. It's my responsibility as the eldest child to provide for them since our father abandoned us." Because participants have to work and cater for their basic needs such as shelter, food, clothing and education, they reported that they mostly feel content with being responsible for their lives. Additionally, as Koko put it, "I'm happy my mother and siblings respect me a lot for what I do for them", they take pride in being bread winners for their families most especially where family members acknowledge their contribution to the family survival.

\section{c) Educational attainment}

Educational attainment is a very crucial issue for most child laborers at the study site. Most participants believe that child labor means the opportunity to access education which would have been otherwise impossible due to parental neglect or unemployment. The following excerpt reveals this:

\author{
I work so I could go to school (Koko) \\ I used my money to pay for my fees like PTA dues and books (Chris) \\ My work supports my schooling (Joe) \\ I take special interest and likeness to children who are working \\ and still going to school. I'm very proud of them. (Mama Joy)
}

All participants reported that the product of their work is what has either put or kept them in school. Working whilst in school was purposeful. In effect there are three main aims; firstly, to go to school or continue schooling in order to acquire formal education, secure a good job, and get out of the financial straits. Secondly, to enable the participants help alleviate the financial burden on their mothers while they were still in school and eventually when they finish school. And finally, to make them belong and feel at home amongst their peers in terms of their material possessions. 
Sending themselves to school or continuing schooling and possessing material wealth could be considered as immediate goals; finishing school and securing a good job in order to be well-to-do would be the ultimate goal and these in themselves are positive. They motivate the children to work, learn to save and be in school. This then prevents them from dropping out from school. There is, however, a pervasive goal, that is, while the participant is still going to school, he or she will be providing for himself or herself at school and the mother and or siblings at the same time.

\section{Positive Outcomes}

The themes that evolved under this outcome were coded: too busy to err, financial literacy and money making, self support and economic independence, support for parents and siblings among others.

\section{a) Too Busy to Err}

One strong emergent theme of positive outcome of child labor for participants is that child labor kept its victims out of harm's way. Working as a child though generally destructive, seems to have positively affected some participants' life as inferred from their narratives:

Because I work, I do not get the time to be idle and engage in trivial things (petty fighting) that some of the boys of my age do. (Koko) Madam, I don't go out with friends to do anything bad. You see, my friend is Azuma so if I have to go anywhere I go with him. Then we also talk much about how we can stay in school and make it in life. (Joe)

Joe and Koko's statements above clearly reveal a very minor yet significant case that child labor, if managed properly, has positive effects on the child such as putting him in school and also keeping him out of trouble. It is very important to note here that child labor does not always make children truants or delinquents. They believe that their decision to be in school and to work to support themselves is what also makes them focused on their academic work. Though, some child laborers reported that once a while they got involved in petty fights with their friends whom they believe intimidate them because of their situation, female 
participant revealed that they could not get into trouble because most of the times, they were in their homes and the consequences of getting into trouble was severe punishment. However, it could be inferred from the data that in an attempt to keep out of trouble and concentrate on work, these children might as a result, suffer loneliness and social withdrawal which could pose developmental problems in future adult life. Their decision not to be trivial should not be misconstrued as their inability to play. These children play but did not indulge in trivialities such as petty fighting.

\section{b) Financial literacy and Money Making}

The general underlying economic logic of children's engagement in child labor is to make money. It is the desire to go to school or to continue school and be like all other children that seems primarily to drive many participants into work though this drive also brought in its wake the desire to make money.

The money these participants made was also used for the provision of basic needs such as food, clothing, and education. One very important theme gleaned from the narratives of the participants is the issue of saving. Though these children were unfortunately exposed to work earlier than their peers from comparatively better economic homes, some of the child laborers by this same unfortunate condition, learn the art of working for themselves and learning very early in life the rudiments of financial literacy which is saving. A common trend in the narratives regarding this theme is summed up in Dan's statement, "I saved some money I made and that was what I used to go to school". If this attitude is managed properly or nurtured by parents or significant others, these child workers are likely to grow on a sound financial management skills of working and saving or they could as well, be introduced to investments that would ultimately see them financially sound in their adult lives.

\section{c) Self-Support and economic Independence}

Koko engaged in work to fend for himself by looking after himself at school, renting a room for himself and leaving the parental home and consequently parental control. He thus became independent in the true sense of the word: to stop depending on parents whose support was not forthcoming in solving his financial and educational needs. In fact, his basic 
needs were not catered for by his parents. The attraction of the returns of working at the fishing community that seems to provide some sense of independence from unsupportive parents was very strong. To free himself from the shackles of an irresponsible or incapable father and unemployed mother, the prospect of the "small small money" made at the beach was worth the odds.

Joe shared similar experience with Koko when he reported that he engaged in work because his father refused to provide for him after several appeals made to him. He said that though he lived with his auntie, he was virtually on his own. He intimated, "I live with my auntie but I do everything for myself". In fact the expression, "I do everything for myself" indicates that Joe is independent from his parents and even his auntie. These participants also engaged in work as children to care for themselves and be self sufficient. The choice to work has thus made these children their own bosses and they tend to control themselves. It is evident that there is loss of parental control as a result of parental irresponsibility and economic hardship.

However, some participants reported that though they worked and earned some money, they still remained under their parents' control. They indicated that they listened to their parents as to whether they should work or not and they used part of their earnings on themselves but their parents also decide sometimes what they should use their money for. These participants were of the view that their engagement in child labor was to lessen the burden on their parents but not necessarily to make themselves fully self-reliant. Their work was to supplement what their parents did for them.

\section{d) Support for Parents and Siblings}

Data revealed that child laborers worked so that "it will be good for all of us" as indicated by Koko. At the tender age of 10, Koko not only saw the need to work to send himself to school, but also to assume the responsibility of supporting his siblings by giving money to his mother. Joe indicated that though he did not give his auntie money, he sometimes "brings fish home for cooking". Dan also shared similar experience with Chris and said that, "When I work, the money I make I give some to my mother... the fish I bring home, my mother uses it to cook for 
us". The stories of Joe and Dan were corroborated by Mama Bea and Mama Joy that children who work are source of support for the family.

It is clear that responsibility for siblings may not directly be the pull or push factor for child labor in the fishing communities. However, most child laborers support their families with what they earn and this makes their financial contribution to the family maintenance and survival very crucial. This indicates that some of the participants have indirectly assumed adult responsibility of providing for themselves and their families: their mother and siblings a job for the family head - the father. These children have, therefore, become the family breadwinners leading a premature adult life.

\section{Discussion}

On the score of the two main themes of positive personal meaning and positive outcomes, many findings emerged. For positive outcomes, first, the study found that most participants were kept out of harm's way because they engaged in child labor. The study found that participants did not engage in drug and alcohol use, and were not school drop-outs and social deviants as usually reported by researchers such as (Dworetzky, 1993; Eshun, 2006; Farrell, Hains, \& Davies, 1998; Omokhodion, Omokhodion, \& Odusote, 2006) that adolescents who engaged in work during school years suffer more drug and alcohol use, and greater delinquency. This conclusion by these researches might be based on the kind of work the child laborers studied engaged in, and their environment. Of course, a child laborer peddling drugs on the street has high chances of crossing over from a pusher to a consumer. For positive personal meaning, the study found that in spite of the negatives associated with child labor, the phenomenon indeed, has positive stigma and that most often there is some form of household pride when children combine work with school. This also confirms the works of Admassie, (2003) and Zierold et al., (2004) that child labor provides child laborers positive self-identity and self-reliance. Positive personal meanings such as freedom, independence and educational attainment modelled on positive stigma. It was found that children forced into child labor found some sense of positivity in their otherwise bad situation where they chose to be free. Their sense of freedom resulted in their 
rationalisation that man chooses and becomes what he wants to be. To be a child laborer does not mean one should be condemned to perpetual penury or meaninglessness in life. Forced to be, but not chose to be, a child laborer still can choose to find positive personal meaning in their child labor conditions specifically and life in general.

Results show that two participants were their school's prefects: Boys' and Girls' school prefects in their school. In the face of this unfortunate circumstance in their lives, they were deemed fit and elected for these positions and in fact, their school's records indicated that they were among the best academic performers in their school. This finding resonates well with the declaration of Victor Chipani that "we as child workers can achieve anything" (Sceppacerqua, 2014).

This study also found that the participants made good use of their condition by turning a negative situation into a positive one where they avoided bad company, used child labor to either put themselves in school or stay in school, and believed they can make it in life. They learn to understand their conditions as child laborers and believe that life is a struggle and if they struggle well, because they have the choice to struggle and make it in life or to give up, the choice to be positive made them to derive positive personal meaning from their sufferings and be proud of their conditions and achievements by combining work with schooling. This finding is in line with a positive stigma model (Lopez-Calva, 2002; Patrinos \& Shafiq, 2008) which proposed that actions and policies that increase schooling and socioeconomic status are not motivating enough to eliminate child labor in households that have positive attitude toward child labor.

\section{Recommendations for Counseling}

Counseling is an indispensable issue in the fight against child labor though most organizations at the forefront of the fight seem not to acknowledge this and do not engage the services of professional counsellors in their institutions. In the complexities of work related issues where poverty and unemployment are rating high, and care and love for children are missing, it is important that counselors should rise up to their role of providing care and empowerment to children caught up in child labor. Providing direction and guidance 
especially to children who have found their place in work should be paramount on the counsellors' agenda. Counselors need to assist these children by encouraging them to learn to manage the little time they have to attend to their work and also learn at school to achieve positive outcomes from child labor.

They could also help child laborers in finding the kind of job that would not interfere too much with their education yet will bring them some income. Indeed, relating the existential approach, counsellors could give meaning in life and hope for a better future to these children. Their engagement with this vulnerable group will give them motivation to work and get their education in a better way.

It is also recommended that values of work that lead to self-reliance and self sufficiency and dignity of labor should be emphasised in schools and community gatherings. The Ghana Education Service should modify school curricula and programmes to suit school children who work. This could be done where holidays coincide with the planting and harvesting seasons to maximise their stay in school whilst making money to support themselves. In this regard, the double-tracking system can also help children who have to work to support themselves to do so during holidays.

\section{Conclusion}

Children work because of poverty. Child labor is bad to a greater extent but one cannot undermine some of its positive outcomes. Surprisingly enough, some children excelled in school because they had intrinsic motivation to learn and to be out of trouble and the only opportunity for them to acquire education is to work. Such children who knew how hard it was to pay for schooling could not afford to fail in school as this would mean going through the tough times of working all over again. Passing examinations brought inner satisfaction and an inspiration to work more. This is a value these children develop towards hard work and excellence. Though the phenomenon is subjective and highly associated with negative outcomes, this study concludes that there were some positive outcomes associated with the experiences of child laborers: that the whole issue of the positivity of child labor depends on the motive and reason for working. If children can use their work to educate themselves 
since most of them are from poor homes and or have parents who are negligent, it will be good, but when the child is exposed to situations that damages his or her mental, moral, and physical state and jeopardises his education, it is bad. However, care must be taken as their defence mechanism of avoiding trouble or associating with peers for fear of intimidation and humiliation could be signals of avoidant personality disorder and agoraphobia. We, therefore, conclude that counseling programmes will enhance children's awareness of how to manage their time and money, and make positive personal meaning out of their debilitating conditions of child labor are likely to have modest effect on reducing child labor.

\section{References}

Admassie, A. (2003). Child labor and schooling in the context of subsistence rural economy: Can they be compatible? Educational Development Policy Paper 23, I67-I85.

Agordzo, N. (20|3). "Push" and "pull" factors influencing junior high school students engagement in child labor in fishing communities in Ghana. Research on Humanities and Social Sciences,3 (4), 67-75.

Agordzo, N. A. (201I). Socio-cultural context of child labor in fishing communities of Cape Coast: implication for policy and school counseling. Unpublished M.Phil thesis submitted to University of Cape Coast, Cape Coast.

Al- Omoush, A. H. (2008). Socio-demographic profile, level of anxiety, and relationship with the father of working children in the city of Amman. (uunpublished masters thesis), Jordan University of Science and Technology.

Arends-Kuenning, M., \& S. Duryea. (2006). The effects of parental presence, parents' education, and household headship on children's schooling and work in Latin America. Journal of Family and Economic Issues,27(3), 263-286.

Basu K. \& Van P.H. (1998). The economics of child labor. The American Economic Review. 88(3), .

Bryman, A. (2008). Social research methods: (3 $3^{\text {rd }}$ ed.). NY: Oxford University Press.

Creswell, J.W. (2003). Research design: qualitative, quantitative and mixed methods approaches. ( $2^{\text {nd }}$ ed.). New Delhi, India. Sage Publications.

Donnellan, C. (Ed.). (2002). Child labor. (Vol. 46). Cambridge: Independence Educational Publishers. 
Dworetzky, J. P. (1996). Introduction to child development. (6 ${ }^{\text {th }}$ ed.), New York, NY: West Publishing Company.

Epie, C. (2004). Redefining work and non-work: a qualitative study comparing the literature and women's subjective experience of work and non-work. Ife Psychologia: an International Journal of Psychology in Africa, I 2(I), I32-I 52.

Eshun, R. (Metropolitan Coordinator). (2006, 26 ${ }^{\text {th }}$ June,). Metropolitan education office: Girl child education unit [Personal Communication] Cape Coast.

Farrell, S.P. \& Hains, A. H. (1998). Cognitive behavioural interventions for sexually abused children exhibiting PTSD symptomatology: Behaviour therapy. Journal of Paediatrics Nursing, 29: 24I-255.

Fyfe, A. (1989). Child labor. Cambridge, England: Polity Press.

Grootaert, C. \& H.A. Patrinos. (1999). The policy analysis of child labor. New York: St. Martin's Press.

ILO/IPEC, (2004). Support for the implementation of time-bound measures for thee limination of the worst forms of child labor in Ghana. Accra: Ghana.

Kottler, J. A. \& Brown, R. W. (1996). Introduction to therapeutic counseling. Boston, USA: Brooks Publishing Company.

López-Calva, L.F. (2002). A social stigma model of child labor, Estudios Economicos, I 7.

May, R., Angel, E. \& Ellenberger, H. (1958). Existence. New York: Simon and Schuster.

Miles, M. B. \& Huberman, A. M. (1994). Qualitative data analysis: An expanded sourcebook. Thousand Oaks, CA: Sage Publications.

Miller, R. B. (1983). A call to armchairs. Psychotherapy: Theory, Research, and Practice,20(2), 208-219.

Omokhodion, F. O., Omokhodion, S. I. \& Odosute, T.O. (2006). Perception of child labor among working children in Ibadan, Nigeria., Ibadan, Nigeria: Blackwell Publishing Ltd.

Patrinos, H. A. \& Shafiq, M. N. (2008). A positive stigma for child labor? The World Bank Human Development Network Education Team Policy Research Working Paper 4697

Patrinos, H. A. \& Psacharopoulos, G. (1997). Family size, schooling and child labor in Peruan empirical analysis. Journal of Population Economics, 15 (I) 47-58.

UNICEF. (20I2). Committing to child survival: a promise renewed. New York: University Press.

Schlemmer, B. (Ed.) (2000): The exploited child, London, England: Zed Books.

Whittaker, A. (1986). "Child labor and its causes", Third World Now: Springfield. 
Journal of Educational, Health and Community Psychology

Vol 7, No 2, 2018 E-ISSN 2460-8467

Nyuiemedi Agordzo Edoh-Torgah

Zierold, K. M, Garman, S. \& Anderson, H. (2004).Summer work and injury among middle school students aged 10-14 years. Occupational Environmental Medicine,6/(4), 518522. 